\title{
Accounting for Business Combinations (Topic 805)
}

\author{
Dahli Gray (Corresponding author) \\ Graduate School Division, Keiser University \\ 1900 W. Commercial Blvd., Fort Lauderdale, FL 33309 \\ Tel: 443-465-4559Ｅ-mail: DGray@ KeiserUniversity.edu \\ Ruben Torres \\ Sr. Accounting Manager, Blink Network LLC \\ 407 Lincoln Rd. Suite 704, Miami Beach, Fl. 33139 \\ Tel. (786) 423-1134Ｅ-mail: Ruben2832@gmail.com
}

Received: March 19, 2019

doi:10.5296/wjbm.v5i2.15031
Accepted: April 6, 2019 Published: September 12, 2019

URL: https://doi.org/10.5296/wjbm.v5i2.15031

\begin{abstract}
This article discusses the Financial Accounting Standards Board (FASB) Accounting Standards Codification (ASC) Topic 805, as promulgated by the 2019 Accounting Standards Update (ASU) concerning Business Combinations. It focuses on revenue from contracts with customers. Several concerns regarding how and when to recognize an assumed liability after a business combination were raised by users and preparers of financial statements. Concerns emerged from the differing views on how a liability (that is, performance obligation) is defined within the FASB ASC Topic 606 regarding revenue from contracts with customers. Determining how and if a contract liability is recognized in a business combination from a revenue contract were the major concerns. This article reviews a brief history of business combinations and contracts with customers. It explores the issue from various accounting perspectives (such as financial and managerial accounting, tax accounting, governmental accounting issues, ethical implications, and international accounting). Potential questions for future research regarding this topic are presented. The 16 Comment Letters sent to the FASB are discussed. The results of a survey administered as part of this research are presented.
\end{abstract}

Keywords: Business combinations, Revenue recognition, Customer contracts, Financial Accounting Standards Board 


\section{Introduction}

This article is based on the Accounting Standards Update (ASU) from the Financial Accounting Standards Board (FASB) on Topic 805 (Business Combinations), issued on February 14, 2019. Comments on the topic were due to the FASB by April 30, 2019. They are analyzed and discussed. The ASU addressed revenue from contracts with customers and recognized an assumed liability. An analysis and overview of the ASU are presented, including the results of a survey. The Proposed ASU (FASB, 2019 February 14) states:

"The FASB has recently issued an update to address revenue from contracts with customers and recognized the assumed liability with a business combination within the scope of Topic 606. The core principle of the guidance in Topic 606 is that an entity should recognize revenue to depict the transfer of promised goods or services to customers in an amount that reflects the consideration to which the entity expects to be entitled in exchange for those goods or services."

Comments concerning the proposed accounting standards update were not due until April 30, 2019. The FASB summarized the 16 Comment Letters on June 2019; key components of the summary are presented in this article. There were concerns about how to apply Topic 805 to a contract with a customer acquired in a business combination after the acquiring company has adopted Topic 606. Within Topic 606 is the concept of performance obligation and if it should be used to determine whether a contract liability is recognized in a business combination from a revenue contract.

\section{History}

The history of business combinations goes back as far as the concept of business goes. The research reported in this article goes back to a period when the concept of how accounting in business combinations is more relevant to accounting standards in the $21^{\text {st }}$ century. The pooling of interests in business combinations has generated debate ever since it was introduced in 1945. In a pooling of interests for a business combination "the assets and liabilities of the combined companies are carried forward at their recorded amounts and retained earnings of the companies were combined" (Rayburn \& Powers, 1991). In 2001, FASB issued the Statement of Financial Accounting Standards (SFAS) No. 141 that addressed the concern that the method of using the pooling method versus the purchase method was producing dramatically different accounting results, therefore moving forward the purchase method was the preferred method to be used (FASB, 2007). The results were expected to provide a better reflection of the investment being made by the acquirer to improve the comparability of reported financial information and provide complete financial information (FASB, 2001). FASB Concept No. 5 (FASB, 2008) states:

"Liabilities that involve obligations to provide goods or services to customers are generally reported at historical proceeds, which is the amount of cash, or its equivalent, received when the obligation was incurred and may be adjusted after acquisition for amortization or other allocations."

Later in 2010 and 2018, Concept No. 8 was introduced, including its concept of notes on the 


\section{Macrothink}

World Journal of Business and Management

ISSN 2377-4622

2019, Vol. 5, No. 2

financial statements to supplement or explain information depicted in words and numbers on the face of financial statements (FASB, $2010 \& 2018$ ). Updates are necessary because stakeholders and the FASB believe there need to be improvements to the standards to address concerns and answer previously unanswered questions. The 2019 guidance offers to establish improved principles which affect the nature, amount, timing, and uncertainty of revenue from contracts with customers. The FASB (2019, February 14) states that the new guidance.

- Removes inconsistencies and weaknesses in existing revenue requirements

- Provides a more robust framework for addressing revenue issues

- Improves comparability of revenue recognition practices across entities, industries, jurisdictions, and capital markets

- Provides more useful information to users of financial statements through improved disclosure requirements

- Simplifies the preparation of financial statements by reducing the number of requirements to which an organization must refer.

\subsection{The New Guidance}

The new guidance establishes the core principle in recognizing revenue to depict the transfer of promised goods or services to customers in an amount that reflects the consideration to which the entity expects to be entitled in exchange for those goods or services (FASB, 2019). The core principle states that revenue will be recognized as the amount the company expects to be paid by the customer in exchange for goods or services. The company needs to apply five steps to achieve the core principle:

- Identify or enter a full contract with the customer

- Within the contract, the performance obligations must be identified

- The transaction price must be identified

- The allocation of the transaction price to the performance obligation needs to be stated in the contract

- Recognize revenue when the terms within the contract are satisfied

Klynveld Peat Marwick Goerdeler (KPMG), describes that an entity needs to apply the acquisition method for each business combination. The acquisition method requires all of the following steps:

a. Identifying the acquirer

b. Determining the acquisition date

c. Recognizing and measuring the identifiable assets acquired, the liabilities assumed, and any non-controlling interest in the acquiree.

d. Recognizing and measuring goodwill or a gain from a bargain purchase. 
The new guidance standards are only applicable to public reporting companies. The FASB (FASB, 2019 February 14) states:

Companies either enter into contracts with customers to transfer goods or services or enter into contracts for non-financial assets unless those contracts are within the scope of other standards such as with insurance contracts or lease contracts.

Currently, under Accounting Standards Codification (ASC) 805, there is no specific guidance as to how or when an organization should recognize or measure liabilities from revenue contracts with customers within the scope of ASC 606, Revenue from Contracts with Customers (Grant Thornton, 2019). "Stakeholders have indicated that there are differing views on whether the new concept of a performance obligation defined in Topic 606 should be used to determine whether a contract liability is recognized in a business combination from a revenue contract" (FASB, 2019 February 14). Prior to the adoption of ASC 606, a liability for deferred revenue or revenue from a contract was recognized in the acquiring company's financial statements, but only if it represented a legal obligation as is with a binding contract. The proposed update to Topic 805 suggests that it would be required for the acquirer to recognize a liability assumed in a business combination from a contract with a customer if that liability represents an unsatisfied performance obligation under ASC 606 for which the acquired company received payment from the customer. What ASC 606 tries to explain is that there are circumstances in which a customer paid the company (acquiree) in full but did not receive the goods or services for which the customer has yet to receive the goods or services. Therefore, the acquirer is liable to provide the goods or services to the customer. "According to the proposal, an organization should recognize deferred revenue from acquiring another organization if there is an unsatisfied performance obligation for which the acquired organization has been paid by the customer" (Tysiac, 2019).

The problem here lies within the contract obligation itself and how it is defined under current accounting standards. Because there is no guidance offered as to how a company should report such an occurrence, there needs to be additional guidance offered by the FASB on the matter. The issue also affects the customer who has paid for a service or product that was never fulfilled or received. The customer can file litigation with the acquiring company, demanding the goods or services to be satisfied. However, litigation claims are not capitalized and are immediately expensed, which reduces operating profits. Obviously, litigation is not the path most individuals and companies would like to take, especially when there was a contract in place.

The Public Company Accounting Oversight Board (PCAOB) issued the Security and Exchange Commission (SEC) Filing Form 19b-4, which includes the proposed rules on contracts with customers. The docket (PCAOB, 2019) states:

Accounting estimates are pervasive to financial statements, often substantially affecting a company's financial position and results of operations. Examples of accounting estimates include certain revenues from contracts with customers, valuations of financial and non-financial assets, impairments of long-lived assets, allowances for credit losses, and contingent liabilities. 


\section{Mll Macrothink}

World Journal of Business and Management

ISSN 2377-4622

2019, Vol. 5, No. 2

The docket proposes that a fair value measurement is considered a form of an accounting estimate. It shares similar characteristics with other estimates, which includes subjective assumptions and measurement uncertainty.

International business combinations standards maintain a similar strategy as business combinations in the United States. International Accounting Standard (IAS) 10 states that the parent company that owns the subsidiaries is required to present consolidated financial statements (IAS Plus, 2019). When there is a business combination, the acquirer is considered the parent company when it owns a majority of the other company at 51 percent. IAS 10 deals with the events after the reporting period. "Acquisitions by an investment entity of a subsidiary that is required to be measured at fair value through profit or loss" (IFRS, 2019b). There are adjusting events and non-adjusting events. Adjusting events provide evidence of conditions that exist at the end of the reporting period. This situation is because, often, events are in the process of occurring at the end of the period, which should be considered. However, they are not considered as of the date of the last day of closing. The non-adjusting events are simply events that will not require any adjustments after the reporting period. The adjustments can either be favorable or unfavorable. An example of an adjusting event could be litigation against the company that existed prior to the end of the reporting period because the litigation provides evidence of an existing amount of liability prior to the reporting date. "If an entity declares dividends after the reporting period, the entity shall not recognize those dividends as a liability at the end of the reporting period. That is a non-adjusting event" (IAS Plus, 2019).

Ernst and Young (EY) (2019) wrote a publication on how FASB is seeking input on the measurement of contract liabilities assumed in a business combination. This topic was introduced in February 2019 with comments on the document itself due by April 30, 2019. The FASB issued an invitation to comment on topics from stakeholders asking whether any final guidance should address both the recognition and measurement topics. The FASB was looking to clarify when contract liabilities should be recognized. Most members agree that the amount of revenue recognized by an acquirer for two contracts with identical unsatisfied performance obligations should be the same, regardless of the timing of payments. Thus, the invitation to comment (ITC) was looking for input on whether the timing of payments related to an acquired revenue contract should affect the amount the acquirer recognizes after a business combination. There are situations in which the timing of payments might affect the amount of revenue an acquirer recognizes according to Revenue Recognition 606. However, in the situations when the timing of payments should not affect how much revenue is recognized by the acquirer, whether a type of identifiable asset (and what type) should be recognized at the acquisition date is considered. "The scenarios focus on revenue recognition because the total amount of income recognized by the acquirer post-acquisition likely would not be affected by any guidance provided on the timing of payments" (EY, 2019). The ITC was looking for input on what types of costs expected to be incurred to fulfill a performance obligation should be included in the fair value measurement of a contract liability that would be recognized under the proposal. 


\section{Summary of the Comment Letters}

While the concept of a performance obligation, as defined in Topic 606, was generally supported, there were concerns about the measurement and reporting process (FASB, 2019 June 13, p. 4). A concern was raised that "determining the fair value of the obligations may be complex and lead to diversity in practice (Ibid., p. 5). There were differing opinions as to whether the change in accounting practice would increase preparer costs along with user confusion (Ibid., p 6). The EITF noted the possibility of issuing "a final Update during the third quarter of 2019" (Ibid, p. 13). Until then (that is, July, August or September of 2019), the accounting for the issue, which is the focus of this article, will remain unresolved.

\subsection{Managerial Accounting Aspects}

In a business combination, the main goal of the acquiring company is not to overpay, and the goal of the company being acquired is to avoid selling for too little. Negotiation is a big part of a business combination. Within the negotiations, the acquiring company requires financial statements from the acquiree to analyze the financial health of the company. Thus, to bring the valuation of the company to a more accurate figure, businesses use what is known as an earnout. "Earnouts have several advantages: They allow buyers to pay part of the purchase price [when] certain goals are met; they allow sellers to receive a higher transaction value when the business performs to their expectations; and they motivate key employees to stay involved with the continued operation of the business" (Schaeffer, 2018). Earnouts will allow the acquirer and the seller to both get the most out of the business combination. An earnout is like a payment that is contingent upon several set goals. The acquiring company sets the goals and payment amounts. This way, the company can gauge a better understanding of the financial health of the company they are acquiring. ASC 805 allows earnouts to be classified as compensation, liabilities, equity, or assets. "If the performance is insufficient or regulatory hurdles are not cleared, the seller may have to reimburse the buyer, and the buyer has a contingent asset rather than a liability" (Schaeffer, 2018). Once the acquirer has complete control of the acquiree, the company that is acquired loses complete control. This generally means that the selling company is now dependent on the management of the acquirer who will determine the performance of the company. "Since the buyer is on the hook for payments under the earnout, the buyer has the incentive to try to manage the performance of the acquired business to avoid paying earnout" (Frankel, 2005). If the earnout is big enough, it can create an incentive for the acquiring company to damage the performance of the acquired company to avoid paying earnout. Unfortunately, even though there is a risk, a contingent payment is sometimes the only way two businesses can negotiate a business combination. As of yet, even after ten years after FASB released what is now known as ASC 805, there is still no authoritative standard in dealing with the fair value of earnouts. The same can be said on how contract liability is recognized in a business combination from a revenue contract.

\subsection{International Aspects}

International Financial Reporting Standards (IFRS) 10 maintains that the parent company that owns smaller subsidiaries is required to present consolidated financial statements (IFRS, 2019a). When there is a business combination, the company is considered the parent 
company when it owns a majority of the other company at 51 percent. IAS 10 deals with the events after the reporting period. IFRS 3 states that "acquisitions by an investment entity of a subsidiary that is required to be measured at fair value through profit or loss" (IFRS, 2019a). There are adjusting events and non-adjusting events. Adjusting events are those events that provide evidence of conditions that exist at the end of the reporting period. This definition is because there are times when events in the process of happening at the end of the period should be considered; however, they are not considered as of the date of the last day of closing. The non-adjusting events are simply events that will not require any adjustments after the reporting period. These adjustments can either be favorable or unfavorable. An example of an adjusting event could be litigation against the company that existed prior to the end of the reporting period. This situation is because the litigation provides evidence of an existing amount of liability prior to the reporting date. "If an entity declares dividends after the reporting period, the entity shall not recognize those dividends as a liability at the end of the reporting period. That is a non-adjusting event" (IAS Plus, 2019). Deloitte (2019) also points out several key differences in business combinations between IFRS standards and the generally accepted accounting standards (GAAP) of the United States (U.S.). The areas in which differences exist are highlighted as follows.

The measurements of non-controlling interest in a business combination, contingent assets and liabilities, transactions between entities under common control, pushdown accounting, operating leases, and the definition of a business (Deloitte, 2019).

One of the most notable differences is in the derecognition of financial assets.

IFRS Standards and U.S. GAAP have different models for the determination of whether a transferred financial asset qualifies for derecognition. Under U.S. GAAP, an entity applies a control-based model and derecognizes assets when control is surrendered. Under IFRS Standards, an entity applies a multistep derecognition model that always considers the risks and rewards of ownership and may include an assessment of control over a transferred financial asset (Deloitte, 2019).

\subsection{Financial and Auditing Aspects}

The PCAOB (2017) published the Staff Audit Practice Alert No. 15, which deals with auditing revenue from contracts with customers. Within the document, Staff Audit Practice Alert No.15 discusses fraud risks, revenue recognition, disclosures, internal control over financial reporting and transition disclosures, and transition adjustments. There is a new five-step revenue recognition model as well as new disclosures such as qualitative and quantitative information about revenue recognized from contracts with customers. The new disclosure requirements at some costs require contractors to obtain or fulfill a full contract with the customer (PCAOB, 2017). The PCAOB (2019) issued SEC Filing Form 19b-4, which includes the proposed rules on items like contracts with customers. The docket states that the accounting estimates are pervasive to financial statements, often substantially affecting a company's financial position and results of operations. Examples of accounting estimates include certain revenues from contracts with customers, valuations of financial and 
non-financial assets, impairments of long-lived assets, allowances for credit losses, and contingent liabilities (PCAOB, 2019). The docket proposes that a fair value measurement is considered a form of accounting estimate because it shares similar characteristics with other estimates, which include subjective assumptions and measurement uncertainty.

\subsection{Tax Accounting Aspects}

The FASB 805-740-10-30-27 (n.d.) states that:

The consolidated amount of current and deferred tax expense for a group that files a consolidated tax return shall be allocated among the members of the group when those members issue separate financial statements.

The sum of the amounts allocated to individual members of the group may not equal the consolidated amount. Under certain conditions, the standards allow for an acquired entity to retain its historical basis in separately issued financial statements after an acquisition (FASB, 805-740-25-12, n.d.). According to FASB, 805-740-25-13 (n.d.):

If there is a continuation of the historical basis for financial reporting while there is a concurrent tax basis step-up, any one of the following three methods is acceptable for allocating the consolidated tax provision:

- Modify the intra-entity tax allocation agreement so that taxes are allocated to the acquired entity on the pre-acquisition tax basis

- Credit the tax benefit from the tax basis step-up to the acquired entity's additional paid-in capital when realized

- Credit the tax benefit to the income of the acquired entity as a permanent difference when realized.

\subsection{Governmental Issues}

The government has no issues with business combinations because there are no business combinations with the government per se, but there are government combinations. Under the Government Accounting Standards Board or GASB (2013), Statement No. 69, there is a mention of government combinations and disposals of government operations. In the government, just as with a business, there are mergers, acquisitions, and transfers of operations. There is a difference between a government merger and a government acquisition. The document defines a government merger to include combinations of legally separate entities without the exchange of significant consideration (GASB, 2013). The assets and liabilities in a government merger are taken at their carrying value. The carrying value is the original cost of the asset; then remove any accumulated depreciation or amortization and also take away the asset impairments. The statement's purpose is to provide guidance about government combinations and disposals of government operations and describes that disclosures are required on these actions. The reason is to allow users to evaluate the nature and financial effects of the transactions. Statement No. 69 "also improves the decision usefulness of financial reporting by requiring that disclosures be made by governments about 
combination arrangements in which they engage and for disposals of government operations" (GASB, 2013).

\subsection{Potential Ethical Issues}

Fraud is everywhere, and considering the consequences in which fraud has in the accounting world, it can cost investors billions of dollars. There are many ways in which a company can have fraudulent information in their financial statements, and it is up to the auditor to catch it. The PCAOB (2016) released AS 2401 in consideration of fraud in a financial statement audit. Fraud is not often committed at the onset because it would be easier for auditors to catch the fraudulent activity right away. The companies that attempt to commit any fraudulent activity know this; thus, the fraudulent activity is committed at the end when all the auditors are busy. There is a greater chance for the fraud to pass unnoticed by the auditors.

There is always something in a company's financial statement that is missed. Multiple people review these documents, and even then, something could be either overlooked or misstated. A material misstatement is something that is typically difficult to hide. Something that is material, usually, sticks out like a sore thumb. It may require a more extensive effort to hide it in plain sight rather than conceal it. By hiding the material misstatement in plain sight, the company can have the misstatement happen throughout the period such that sufficient misstatement would convince the auditor(s) that it is acceptable. "Because material misstatements in financial statements due to fraud can occur throughout the period and may involve extensive efforts to conceal how it is accomplished, the auditor should consider whether there also is a need to test journal entries throughout the period under audit" (PCAOB, 2016).

Enron was one of the most monumental frauds in history, and the main reason for the Sarbanes-Oxley Act of 2002. Enron was infamous for making deals with different companies, like Blockbuster Video, which were called off. However, Enron continued to post profits from the deal. "As of December 31, 2000, Enron assigned a fair value of $\$ 125$ million to its Braveheart investment and a profit of $\$ 53$ million from increasing the investment to its fair value, even though no sales had been made. Enron recorded additional revenue of $\$ 53$ million from the venture in the first quarter of 2001, although Blockbuster did not record any income from the venture and dissolved the partnership in March 2001" (Haswell \& Evans, 2018). This situation brings up the very public and unethical role that Arthur Andersen played in shredding the evidence of the fraudulent activities of Enron. "Andersen had issued unqualified opinions on all of Enron 's annual financial statements through the year 2000 and provided advice on their complex financial transactions" (Hartgraves, 2004).

Another aspect of accounting for business combinations that may have unethical implication concerns earnouts. With an earnout, the acquirer pays incentive to the acquiree for accomplishing a goal, reaching a milestone, or reaching a pre-determined goal set by the acquirer. Generally, it is the acquirer that set the terms and amount paid. Under ASC 805, earnouts are classified as compensation, liabilities, equity, or assets. The ethical implications take effect after the acquirer takes control of the acquiree. Since the earnout is still in effect, it is a possibility that the parent company may try to avoid more payments under the earnout 


\section{Macrothink}

World Journal of Business and Management

ISSN 2377-4622

2019, Vol. 5, No. 2

agreement by deliberately hindering the performance of the acquired company. This information impacts the research on business combinations and revenue from contracts with customers potentially because there has been no guidance offered on the topic. There is still some degree of uncertainty that may provide for a gap in which fraud can be committed.

\section{Survey Analysis}

The survey is about Topic 805. The survey consisted of questions relevant to recognizing an assumed liability and revenue from contracts with customers. A total of 11 responses were gathered for analysis:

Q1

$\$$ Customize Save as $\nabla$

\section{When one organization purchases all or part of another organization, should the acquired obligation to pay liabilities be reported at the historical or fair market value of the amount owed?}

Answered: $11 \quad$ Skipped: 0
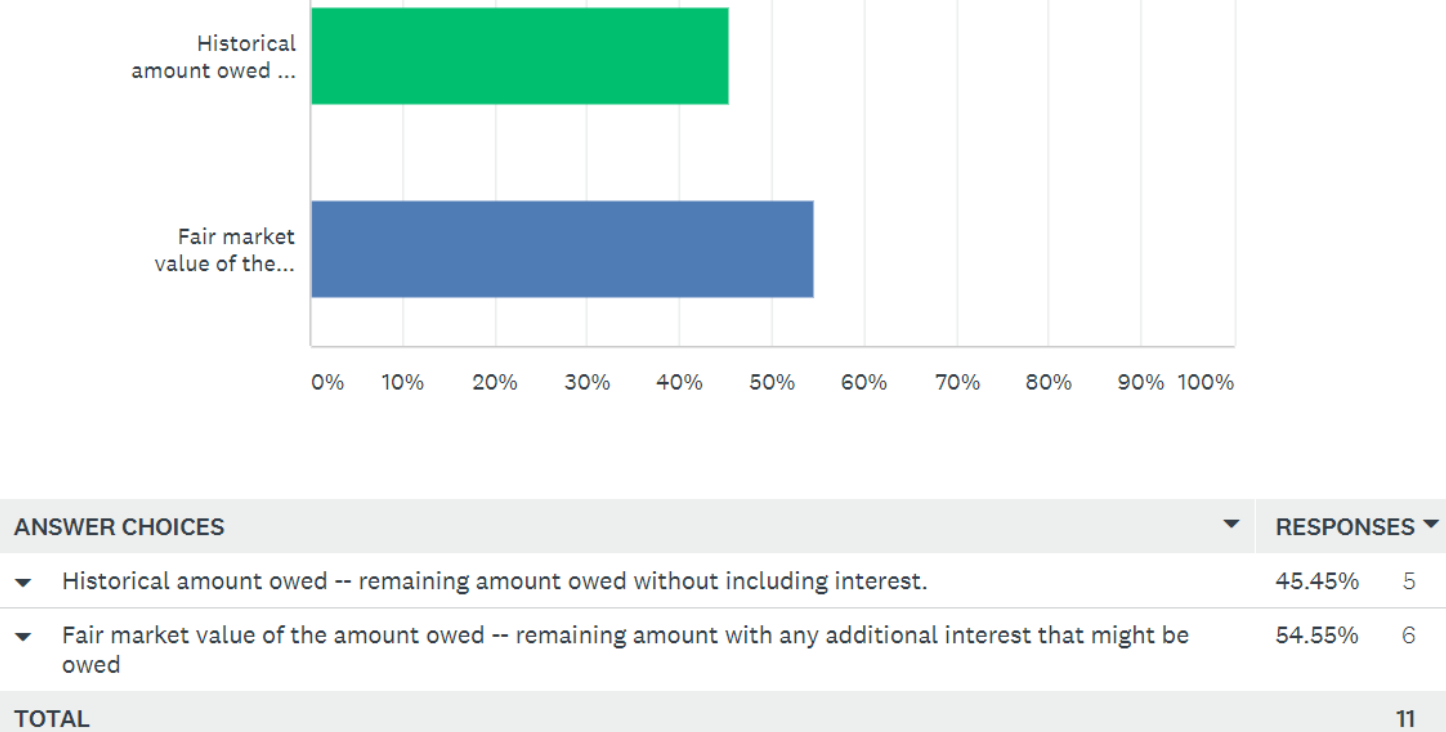

Figure 1. Question 1

The responses were nearly a 50/50 split with fair market value earning the majority of the favor. Generally, people may believe that the fair market value may be a stronger choice because the additional interests are still part of the obligation. 
After a business combination, do you feel it is appropriate for the acquirer to not report the acquired organization's financial statements to the U.S. Securities and Exchange Commission?

Answered: 11 Skipped: 0

Yes

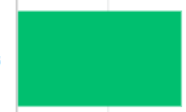

No

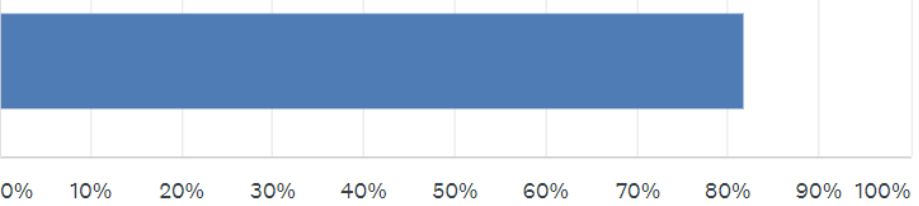

\begin{tabular}{lll} 
ANSWER CHOICES & RESPONSES & - \\
- YES & $18.18 \%$ & 2 \\
\hline NO & $81.82 \%$ & 9 \\
\hline TOTAL & & 11
\end{tabular}

Figure 2. Question 2

Over 80 percent of the votes are in favor of "no." The strong opinion of the population from the surveyed is that a business should not conceal the acquired company's financial information. One can understand that it may provide more useful information, such as whether the acquired company was performing well and was not in a financial crisis prior to being acquired. By not showing the acquired company's financial information, the public cannot know how the new company will benefit the parent company. 
If the accounting for a business combination is not complete by the end of the reporting period in which the combination took place, the acquirer has a period of time to finalize the accounting. How much time do you feel is appropriate for the acquirer to finalize the accounting?

Answered: 11 Skipped: 0

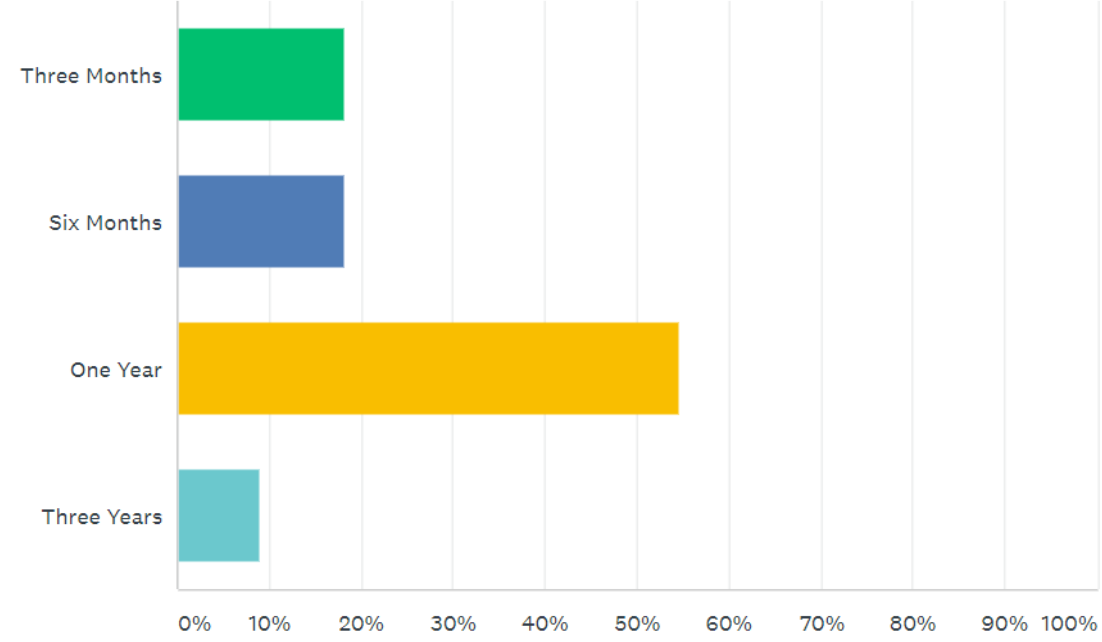

\begin{tabular}{lll}
\hline ANSWER CHOICES & RESPONSES \\
\hline Three Months & $18.18 \%$ & 2 \\
\hline Six Months & $18.18 \%$ & 2 \\
\hline One Year & $54.55 \%$ & 6 \\
\hline Three Years & $9.09 \%$ & 1 \\
\hline TOLAL & & 11
\end{tabular}

Figure 3. Question 3

Three years may be too much time, while three to six months may be considered an appropriate amount of time. However, one year seems fair for a company to get its accounting in order and finalize everything. Over 50 percent of the population believe that one year is a fair amount of time. 
If the acquirer plans to satisfy the performance obligation (delivers product or service) of the acquired organization, do you feel the contract liability should be recognized by the acquirer in a business combination?

Answered: 11 Skipped:0

Yes
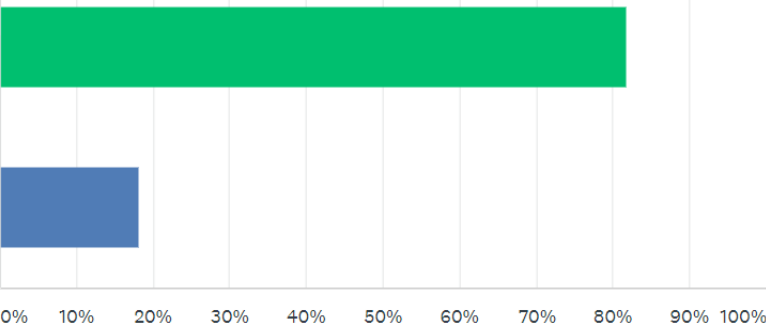

\begin{tabular}{lcc} 
ANSWER CHOICES & RESPONSES & - \\
- YeS & $81.82 \%$ & 9 \\
\hline NO & $18.18 \%$ & 2 \\
TOTAL & & 11
\end{tabular}

Figure 4. Question 4

Over 80 percent of the poll was in favor of the opinion that the acquirer should recognize the contract liability in a business combination.

Do you feel that if a business combination occurs, that the acquirer should restate prior quarter financial statements or that the business combination should only impact current and future periods?

Answered: $11 \quad$ skipped: 0

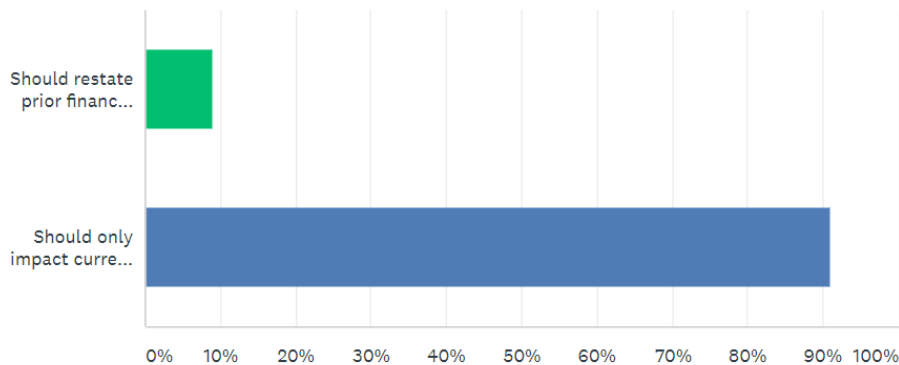

ANSWER CHOICES

- RESPONSES

- Should restate prior financial statements

$9.09 \%$

- Should only impact current and future financial statements

$90.91 \%$

Figure 5. Question 5 


\section{Macrothink}

World Journal of Business and Management

ISSN 2377-4622

2019, Vol. 5, No. 2

All but one person believes that once a business combination occurs, the acquirer should need to restate prior financial statements. It may be possible that the person with that opinion may not be aware of the costs and time involved in restating prior financial periods. Moreover, it may not be of material value to the stakeholders.

Q6

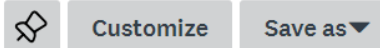

Do you feel that the acquirer should be required to recognize the liability assumed in the contract with a customer in a business combination if that liability represents an unsatisfied performance obligation by the acquired organization even if the customer paid the amount due to the acquired organization?

Answered: 11 Skipped: 0

Yes - the liability in.

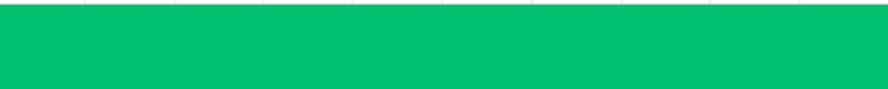

ANSWER CHOICES

RESPONSES

- Yes - the liability in the contract should be recognized

$100.00 \%$

- No - the liability in the contract should not be recognized

$0.00 \%$

TOTAL

Figure 6. Question 6

One hundred percent of the people surveyed voted that the liability in the contract should be recognized if the contract with a customer represents an unsatisfied performance obligation. It is a fair assumption to agree that the acquirer is not liable for the performance obligation. 
Q7

Customize Save as $\mathbf{}$

An entity is typically given a year to finalize its accounting after a business combination. If a company decides on early adoption of proposed amendments of accounting for combinations, do you feel an additional year should be permitted for the acquirer to finalize the accounting?

Answered: 11 Skipped:0

Yes

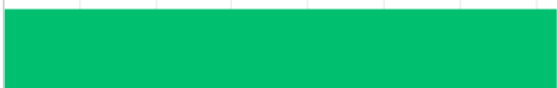

No

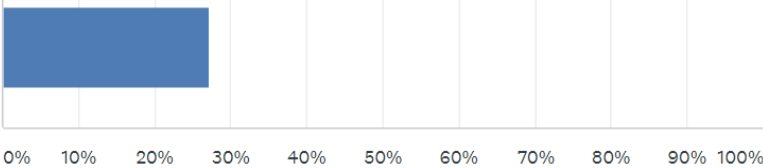

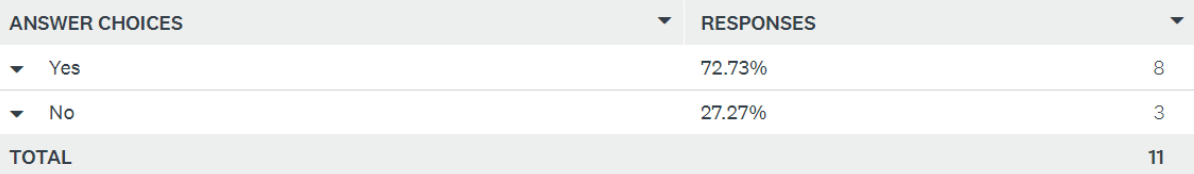

Figure 7. Question 7

Over 72 percent of the people surveyed feel that, as an incentive, if a company decides on early adoption of the proposed ASU, the company should be granted an extra year to finalize their accounting.

Q8

\&) Customize Save as

Do you feel that entities other than public companies should be given an additional year to implement proposed accounting amendments?

Answered: 11 Skipped: 0

Yes

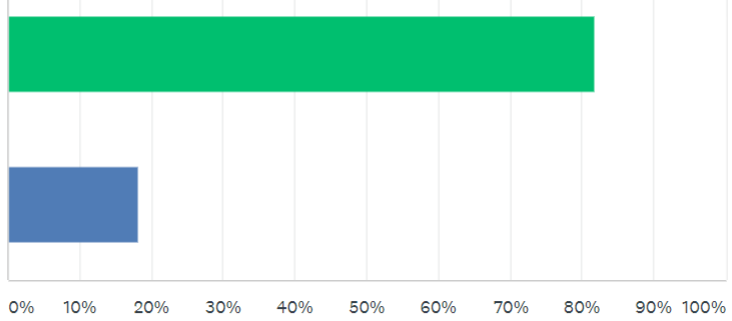

TOTAL

Figure 8. Question 8 


\section{Macrothink}

World Journal of Business and Management

ISSN 2377-4622

2019, Vol. 5, No. 2

It is understood that the proposed ASU is generally required to be used by public companies. If a private company decides to implement the proposed ASU, it would only be fair to give those private companies an additional year to implement the accounting amendments.

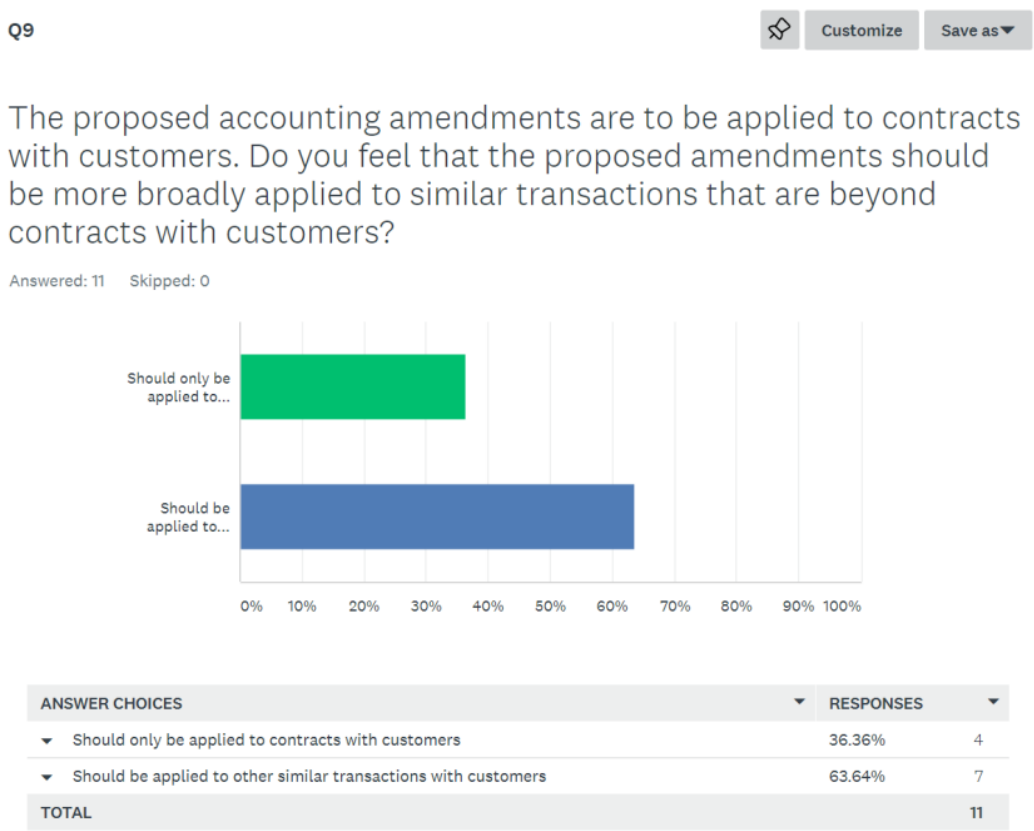

Figure 9. Question 9

The surveyed mostly voted in favor of the proposed amendments, which should be applied to other similar transactions with customers, as well as contracts with customers with unsatisfied performance obligations after the acquiree was paid in full for the services. One can understand that by applying the proposed amendments to other similar transactions, many other issues can be offered more guidance and satisfy more concerns on the topic.

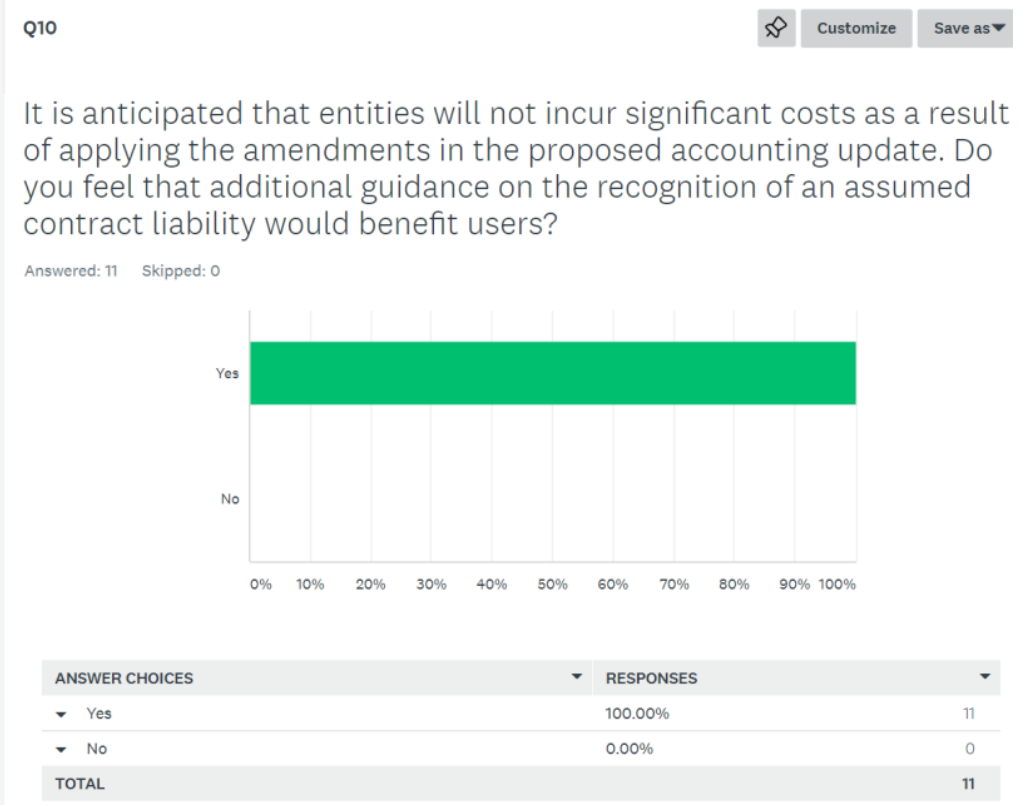

Figure 10. Question 10 
It is unanimously opinionated by the surveyed that additional guidance of an assumed contract liability would benefit users.

\section{Potential Unresolved Future Research Questions}

Within the ASU for Business Combinations (Topic 805) concerning revenue from contracts with customers and how and when to recognize an assumed liability, there will likely be unresolved accounting issues. The EITF is dedicated to guiding this topic, but there are parts of it that will not be resolved. For example, with these updates, one has to wonder if the information provided by the new guidelines will fully satisfy the stakeholders' concerns. The outcomes of financial reporting might not fully provide meaningful information to the stakeholders. Disclosures are always a big part of financial statements, so what kind of disclosures will be necessary to provide meaningful information to the users? Will there be a way for the acquiring company to absorb the assumed liability under the new guidance? After the implementation of the new guidance, what happens if the assumed liability poses a significant and material loss to the company? Should the amount be considered "material" at all since it was the unsatisfied performance obligation of the acquired company? A very interesting question within the proposed ASU seeks to find whether the proposed amendment should be applied to other similar transactions that are not contracts with customers instead of other contracts that fall within the scope of subtopic 510-20; Other Income Gains and Losses from the Derecognition of Non-financial Assets (FASB, 2019). There are also costs involved in satisfying a performance obligation that also needs to be considered and the matter of long-term contracts with customers. What if the acquirer will no longer be providing a certain product or service because the cost is too high, but there is a standing long-term contract of which the performance obligation has not been satisfied either? There is an invitation to comment on the following reporting issues (Grant Thornton, 2019):

- Payment terms and their effect on subsequent revenue recognized

- Costs to fulfill a performance obligation in measuring the fair value of contract liability for a revenue contract under ASC 805

\section{Conclusion}

The proposed ASU deals with a topic that has not previously offered guidance to public companies in the past on specific events that occur in a business combination. After Topic 606 (Revenue from Contracts with Customers) was introduced, the definition of performance obligation was defined in a way that invited conflicting views by stakeholders. Additional guidance was being proposed by the FASB to provide more clarity on the subject. If there is an unsatisfied performance obligation where the acquiree has received the total amount due from the customer, then the acquirer needs to recognize the assumed liability from that contract with the customer in a business combination. Previously as described by the FASB in 2001, the pooling method produced different accounting results. FASB Concept No. 5 offered further clarity that liabilities that involve obligations should be reported at historical values, that is the remaining amount without including interests. Last year in 2018, Concept No. 8 was introduced to further supplement and answer previously unanswered questions 
from the stakeholders. The new guidance offers more guidance on business combinations and contracts with customers. A more robust framework to address revenue issues, as well as inconsistencies and material weaknesses in existing revenue requirements, is offered. The new guidance provides more useful information to offer more clarity on the stakeholders' current state of confusion on the definition of a performance obligation and how it should be treated in financial statements in a business combination.

The problems the proposed ASU rectifies are not new; they are unresolved issues that have surfaced in lieu of other amendments that have only just uncovered what has not been resolved. There is no current law or other regulation that has been proposed to solve or rectify the issues the proposed ASU is tasked with fixing or offering new guidance on. There will be new issues arising after the proposed ASU is amended because there will always be a new kind of negotiation between two businesses to bring forth a business combination that will be fundamentally different from what is discussed in any topic in accounting today.

\section{References}

Deloitte. (2019). A comparison of IFRS standards and U.S. GAAP bridging the differences. Deloitte. $\quad$ Retrieved from https://www2.deloitte.com/us/en/pages/audit/articles/us-aers-a-comparison-of-ifrs-standardsand-us-gaap-bridging-the-differences.html

Ernst \& Young (EY). (2019, February 15). FASB seeks input on measurement of contract liabilities assumed in a business combination. EY. Retrieved from https://www.ey.com/publication/vwluassetsdld/tothepoint_05628-191us_issue18-a_15februar y2019/\$file/tothepoint_05628-191us_issue18-a_15february2019.pdf?OpenElement

Financial Accounting Standards Board (FASB). (2010, September). Statement of financial accounting concepts no. 8: Conceptual framework for financial reporting. FASB. Retrieved from https://fasb.org/cs/ContentServer?c=Document_C\&cid=1176171111398\&d=\&pagename=FA SB\%2FDocument_C\%2FDocumentPage

FASB. (2018, August). Conceptual framework for financial reporting: Chapter 8, notes to financial statements. FASB. from https://www.fasb.org/jsp/FASB/Document_C/DocumentPage?cid=1176171111790\&accepted Disclaimer=true

FASB. (2008). Statement of financial accounting concepts no. 5: Recognition and measurement in financial statements of business enterprises. FASB. Retrieved from https://fasb.org/jsp/FASB/Document_C/DocumentPage?cid=1218220132773\&acceptedDiscl aimer=true

FASB. (2001, June). Statement of financial accounting standards no. 141: Business combinations (as issued). FASB. from https://www.fasb.org/jsp/FASB/Document_C/DocumentPage?cid=1218220124901\&accepted Disclaimer=true 
FASB. (2007, December). Statement of financial accounting standards no. 141: Business combinations (Revised 2007). FASB. Retrieved from https://www.fasb.org/jsp/FASB/Document_C/DocumentPage?cid=1218220124931\&accepted Disclaimer=true

FASB. (2019, February 14). FASB exposure draft proposed accounting standards update (ASU): Business combinations (topic 805) revenue from contracts with customers-Recognizing an assumed liability. FASB. Retrieved from https://www.fasb.org/jsp/FASB/Document_C/DocumentPage?cid=1176172099187\&accepted Disclaimer=true

FASB. (n. d.). Accounting Standards Codification (ASC) 805-740-10-30-27. FASB. Retrieved from_https://asc.fasb.org/link\&sourceid=SL4603008-128506\&objid=117412053

FASB. (n. d.). ASU 805-740-25-12. FASB. Retrieved from https://asc.fasb.org/section\&trid=2899308\#d3e9998-128506

FASB. (n. $\quad$ d.). ASC 805-740-25-13. FASB. Retrieved from https://asc.fasb.org/section\&trid=2899308\#d3e9998-128506

FASB. (2019, June 13). EITF issue no. 18-A, "Recognition under topic 805 for an assumed liability in a revenue contract: Re-deliberations. FASB. Retrieved from https://fasb.org/cs/ContentServer?c=Document_C\&cid=1176172795411\&d=\&pagename=FA SB\%2FDocument_C\%2FDocumentPage

Frankel, M. E. S. (2005). Save that deal using earn-outs. The Journal of Corporate Accounting \& Finance, 16(2), 21-25. Retrieved from https://search-proquest-com.prx-keiser.lirn.net/docview/201616158?accountid=35796

Governmental Accounting Standards Board (GASB). (2013). Summary of statement no. 69 Government combinations and disposals of government operations. GASB. Retrieved from https://www.gasb.org/jsp/GASB/Pronouncement_C/GASBSummaryPage\&cid=11761606365 04

Grant Thornton. (2019 February 21). On the horizon: Proposed ASU addresses acquired revenue contracts. Grant Thornton. Retrieved from https://www.grantthornton.com/library/newsletters/audit/2019/on-the-horizon/February/propo sed-ASU-addresses-acquired-revenue-contracts.aspx

Hartgraves, A. (2004). Andersen's role in Enron's failure. The Business Administration, 64 (6), 753-771. Retrieved from https://search-proquest-com.prx-keiser.lirn.net/docview/208925427?accountid=35796

Haswell, S., \& Evans, E. (2018). Enron, fair value accounting, and financial crises: A concise history. Accounting, Auditing \& Accountability Journal, 31(1), 25-50. http://dx.doi.org.prx-keiser.lirn.net/10.1108/AAAJ-04-2016-2525

International Accounting Standards Plus (IAS Plus). (2019). IAS 10 - Events after the reporting period. IAS Plus. Retrieved from https://www.iasplus.com/en/standards/ias/ias10 
International Financial Reporting Standards (IFRS). (2019a). IFRS 10 consolidated financial statements. IFRS. Retrieved from https://www.ifrs.org/issued-standards/list-of-standards/ifrs-10-consolidated-financial-stateme nts/\#about

IFRS. (2019b). IFRS 3 Business combinations. IFRS. Retrieved from https://www.iasplus.com/en/standards/ifrs/ifrs3

Klynveld Peat Marwick Goerdeler (KPMG). (2018, December 5). Business combinations. KPMG. Retrieved from https://frv.kpmg.us/content/dam/frv/en/pdfs/2016/R23_Accounting_for_Bus_Com.pdf

Public Company Accounting Oversight Board (PCAOB). (2016). AS 2401: Consideration of fraud in a financial statement audit. $P C A O B$. Retrieved from https://pcaobus.org/Standards/Auditing/Pages/AS2401.aspx

PCAOB. (2017 October 5). Staff audit alert no. 15. PCAOB. Retrieved from https://pcaobus.org/Standards/QandA/SAPA-15-revenue-accounting-standard.pdf

PCAOB. (2019 March 2). Securities and Exchange Commission (SEC) Form 19-b, rule filing docket 43. Proposed Rules by Public Company Accounting Oversight Board. PCAOB. Retrieved from https://pcaobus.org/Rulemaking/Docket043/2019-02-19b-4-Estimates.pdf

Rayburn, F., \& Powers, O. (1991). A history of pooling of interests accounting for business combination in the United States. The Accounting Historians Journal,18(2), 155-192. Retrieved from http://www.jstor.org/stable/40698059

Schaeffer, J. (2018). The use and valuation of contingent considerations (earnouts) under the new appraisal guidance. The CPA Journal, 88(8), 56-59. Retrieved from https://search-proquest-com.prx-keiser.lirn.net/docview/2185817823?accountid=35796

Tysiac, K. (2019, February 14). FASB addresses deferred revenue in business combinations. Journal of Accountancy. Retrieved from https://www.journalofaccountancy.com/news/2019/feb/fasb-business-combinations-deferred-r evenue-201920655.html 